\title{
Avrupa Birliği Tarihinde Bir Geri Adım: Brexit ${ }^{1}$
}

\author{
Esra Sena TÜRKO² ve Sümeyye GÖKÇENOĞLU ${ }^{3}$ \\ $\ddot{O} z$
}

Birleşik Krallık’ın (BK) 2016 yılında Brexit referandumunda Avrupa Birliği’nden (AB) ayrılma kararı almasıyla AB tarihinde bir ilk gerçekleşmiştir. Brexit müzakere süreci 2017 tarihi itibariyle başlamıştır. Müzakerelerin iki yıl sürmesi ve BK'nin Mart 2019'da AB'den ayrılması hedeflenmiştir. Ancak süreç, belirlenen takvimin gerisinde kalmıştır; BK, henüz $\mathrm{AB}$ üyeliğinden ayrılmamıştır. Çalışmada, BK'nin AB'den ayrılması durumunda Birlik ile ilişkilerini hangi modelde devam ettireceği, müzakerelerde tarafların pozisyon ve stratejileri, olası sonuçları ve ikilinin geleceğine dair ilişkilerine etkileri incelenmiştir. Ayrıca Türkiye'nin Brexit sürecinden ne derecede etkilendiği tartışılmıştır. Bu bağlamda ülkelerin hem politik hem de ekonomik verileri ele alınarak değerlendirmeler yapılmıştır. Brexit sürecinde BK'nin ulusal para biriminin son 31 yılın en düşük seviyeye düştügü, AB ile olan ihracatında \% 20 kayıp yaşadığı, dünya finans piyasasındaki konumunu kaybettiği ve milli gelirinin \% 1-9 arasında daraldığ1 görülmektedir. AB ise en büyük finansman kaynağı olan üyelerinden birini kaybetmiş, dünya üzerindeki saygınlığı kısmen zedelenmiş ve yeni ayrılık söylentileriyle karşı karşıya kalmıştır. Ayrıca Brexit ile Birlik’in dış politikası zayıflamış, ABD gibi bazı ülkelerle ikili anlaşmalarında gecikmeler yaşanmıştır. Türkiye Brexit'ten doğrudan etkilenmiştir. Türkiye’de en fazla yabancı yatırımı bulunan ülkenin BK olduğu ve 2900 'den fazla İngiliz sermayeli şirket bulunduğu bilinmektedir. BK Türkiye'nin ithalat yaptı̆̆ ülkeler arasında 11. sırada, ihracat yaptığı ülkeler arasında ise 2. sırada yer alırken; Brexit sonrası ikili arasındaki dış ticaret \% 14 oranında daralmış ve en çok ihracat gerçekleştirilen ülkeler sıralamasında 4 . sıraya gerilemiştir.

\section{Anahtar Kelimeler: Brexit, Avrupa Birliği, Birleşik Krallık, Türkiye}

\section{One Step Back in European Union History: Brexit}

\begin{abstract}
A first in European Union (EU) history has come true when United Kingdom (UK) decided to leave EU membership by Brexit referendum in 2016. Brexit negotiation process has started by 2017. Negotiations were expected to last for two years and UK to leave EU membership by March 2019. But the process has fallen behind schedule, UK hasn't left EU membership yet. Position and strategies of the counterparts in negotiations, expected possible results and effects on future relations of the counterparts are examined in the study. Besides how Turkey is affected by Brexit process is discussed. Within this context, both political and economic data of the countries and the Union are reviewed. In Brexit process, UK currency has decreased to lowest grade of 31 years, export to EU has declined 20\%, UK has lost her position in finance market and national income narrowed by $1-9 \%$. On the other hand, EU has lost one of her most important finance resource members, her worldwide reputation is partly damaged, and has faced with new exit rumors. Furthermore, Union's foreign policy has been weakened by Brexit, delays occurred in bilateral agreements. Turkey is directly affected by Brexit. UK is known to be the country possessing highest number of foreign investments in Turkey, and there are more than 2900 companies with British capital in Turkey. UK had ranked in 11th place in Turkey's import partners and 2nd place in export partners; after Brexit, foreign trade between two countries has narrowed by $14 \%$ and UK has declined to 4th place among major export countries.
\end{abstract}

Key Words: Brexit, European Union, United Kingdom, Turkey

\section{Atıf İçin / Please Cite As:}

Türko, E. S. ve Gökçenoğlu, S. (2020). Avrupa Birliği tarihinde bir geri adım: Brexit. Manas Sosyal Arastırmalar Dergisi, 9(1), 573-589.

\footnotetext{
${ }^{1}$ Bu çalışma, Aydın/Didim'de düzenlenen IV. Uluslararası Kafkasya-Orta Asya Dış Ticaret ve Lojistik Kongresi’nde (7-8 Eylül 2018) sözlü bildiri olarak sunulan “AB Tarihinde Bir Geri Adım: Brexit” adlı çalışmadan türetilmiştir.

2 Dr. Öğr. Üyesi - Erzurum Teknik Üniversitesi İktisadi ve İdari Bilimler Fakültesi, esturko@erzurum.edu.tr ORCID: 0000-0002-9102-6120

${ }^{3}$ Doktora Öğrencisi - Erzurum Teknik Üniversitesi Sosyal Bilimler Enstitüsü, sumeyye.gokcenoglu51@erzurum.edu.tr - ORCID: 0000-0002-6878-8813
} 


\section{Giriş}

Birleşik Krallık'ın (BK) 2016 yllında Brexit referandumunda Avrupa Birliği’nden (AB) ayrılma kararı almasıyla $A B$ tarihinde bir ilk gerçekleşmiştir. Brexit müzakere süreci 2017 tarihi itibariyle başlamıştır. Müzakerelerin iki yll sürmesi ve BK'nin Mart 2019'da AB'den ayrilması hedeflenmiştir. Ancak süreç, belirlenen takvimin gerisinde kalmıştır; $\mathrm{BK}$, henüz $\mathrm{AB}$ üyeliğinden ayrılmamıştır. $\mathrm{BK}$ Parlamentosu, $\mathrm{AB}$ ile üzerinde uzlaşılan anlaşmayı 3 kez red etmiştir. BK, AB'den iki kez erteleme talep etmiştir. BK Başbakanı May, Muhafazakar Parti'nin liderliğinden ayrılmıştır, yeni parti liderinin Temmuz 2019'da belirlenmesi beklenmektedir. Süreç hala belirsizliğini korumaktadır. Zira, Muhafazakar Parti başkanlığına aday liderlerin, Brexit sürecinin nasıl tamamlanması gerektiği konusunda tavr1 farklılık göstermektedir. Muhafazakar Parti'nin yeni başkanının kim olacağı, ayrılma şartlarını da belirleyecektir (Barnes, 2019).

Maastricht Anlaşması'ndan sonra AB'de üye ülkelerin bazı politikaların dışında kalmaları (opt-out) AB'nin bundan sonra gerçekleşen her anlaşmasında sabit bir özellik haline gelmiştir. Entegrasyon kavramı, merkezileşme, politika birliği ve topraksal genişleme süreci olarak tanımlanmaktadır. Bu bağlamda $A B$, farklılaşmış bir entegrasyon sistemi olarak görülmektedir. "Farklılaşma" her bir üye ülkenin, üyeliğinin kapsamındaki varyasyonları ifade etmektedir. Farklılaşmış entegrasyon sistemleri, dikey ve yatay farklılaşma ile karakterize edilmiştir. Dikey farklılaşma, spesifik politika alanlarında merkezileşmenin düzeyine; yatay farklılaşma, spesifik politika alanlarında üyeliğin kapsamına karşılık gelmektedir. Bu noktadan hareketle farklılaşmayı içsel ve dışsal olarak ikiye ayırmak mümkündür: içsel farklılaşma, en az bir üye ülkenin entegrasyona katılmadığı (örneğin parasal birlik); dışsal farklılaşma ise, en az bir üye olmayan ülkenin entegrasyona katıldığı (örneğin Norveç, İzlanda ve Lihtenştayn'ın Avrupa Ekonomik Alanı'na (AEA) ve Tek Pazar'a katılımı) süreci tanımlamaktadır (Leruth, vd., 2019, s. 1; Schimmelfennig, vd., 2015).

Cameron hükümetinin, BK'nin üyelik koşullarının yeniden müzakere edilmesi ve bir referandum yapılması yönündeki kararı, Avrupa entegrasyonunda yeni bir süreci tetiklemiştir: üye ülkenin entegrasyon düzeyi ve üyeliğinin kapsamında seçici azalma olarak ifade edilebilecek farklılaşmış dezentegrasyon. Farklılaşmış entegrasyonun post-işlevselci açıklaması aynı zamanda dezentegrasyonun dinamiklerini de açıklamaktadır. Bu bağlamda Brexit, self-determinasyona zorlayan entegrasyon etkileri (göçmenlik), Avrupa şüphecisi bir partinin yükselişi ve referandumların uygulanması ile sonuçlanmıştır (Schimmelfennig, 2018, s. 1154).

Brexit sürecinde İngiliz politikasındaki patolojileri inceleyen Gamble (2018), ayrilmayı destekleyen kampanyalarda dile getirilen "kontrolü tekrar ele almanın" ve 40 yılı aşan Avrupalılaşmanın çözülmesinin düşünüldüğgunden daha kolay gerçekleştiğini belirtmektedir. Brexit referandumu; popülizmin yükseldiği, siyasal partilerin yeniden konumlandığı, BK'de toprak bütünlüğünün sarsıldığı ve dış politikada geleceğe ilişkin soruların arttı̆̆ bir süreci beraberinde getirmiştir.

Brexit, AB'yi ve BK'yi derin bir belirsizliğe itmiş, siyasi ve ekonomik yönden çeşitli sonuçlar doğurmuştur. Bununla birlikte $A B$ üyesi diğer ülkeler, Türkiye ve $A B$ üyesi olmayan dünya ülkeleri de Brexit’ten çeşitli açlardan etkilenmiştir. BK-AB arasındaki bu süreci çeşitli senaryolar üzerinden değerlendiren, ileriye dönük ekonomik etkileri araştıran çalışmalar bulunmaktadır. Ancak bu çalısmaların sonuçları kesinlikten uzaktır; çünkü daha önce hiçbir ülke $\mathrm{AB}$ gibi bir büyük bir bütünleşme hareketinden ayrilmamıştır ve modelleme yapılabilecek benzer bir örnek olay yoktur (Hantzsche, vd. 2018).

Bu çalşsmada, BK'nin AB'den ayrılma kararı almasının altında yatan nedenler ve bu kararın sonuçları araştırılmıştır. Brexit sürecinin nasıl işleyeceği, $A B$ 'den ayrılma yönünde ilerletilen müzakereler incelenmiştir. Aynı zamanda Brexit'in $\mathrm{AB}, \mathrm{AB}$ üyesi ülkeler, Türkiye ve $\mathrm{AB}$ üyesi olmayan ülkeler üzerindeki etkileri, geleceğe yönelik beklentiler irdelenmiştir. Brexit konusu, BK'nin iç siyasi dinamikleri (Colantone ve Stanig, 2018, Gamble, 2018), BK ekonomisi (Chen vd., 2018), AB politikalar1 (Armstrong, 2018) ve çeşitli ülkelerin $B K$ veya $A B$ ile diş ticaretinde beklenen değişiklikler (Rothman, 2016; GarciaHerrero ve Xu, 2016; Razzaque, 2017; George, 2017; Wood ve Jang, 2017) gibi spesifik açlardan araştırılmıştır. $\mathrm{Bu}$ araştırmalar içerisinde Brexit referandumu sürecinde ve sonrasında BK'de yaşayan göçmenlerle ilgili dikkat çekici şekilde çok sayıda çalışma gerçekleştirildiği görülmektedir (Arnorsson ve Zoega, 2018; Dennison ve Geddes, 2018; Virdee ve McGeever, 2018). Çalışmada, farklı açılardan Brexit’i irdeleyen araştırmaların sonuçları derlenmiş ve bir arada sunularak değerlendirilmiş̧tir. 


\section{Brexit}

\section{Birleşik Krallık AB'den Neden Ayrıldı?}

Brexit konusunda gerçekleștirilen araştırmalarda, Avrupa şüpheciliği (Euroscepticism) ifadesinin sıklıkla kullanıldığı görülmektedir. Avrupa şüpheciliği ilk olarak Britanya'da ortaya çıkmış zaman içerisinde tüm Avrupa'ya yayllmıştır (Torreblanca ve Leonard, 2013). İfade, Avrupa entegrasyonu sürecine karşı muhalefet ve şüphe olarak tanımlanabilir (Taggart, 1998, s. 365). BK ile AB arasında yakın ilişkinlerin kurulmasına karşı çıkan kişi veya politikacı, Avrupa şüphecisi (Eurosceptic) olarak nitelendirilmektedir (Cambridge University Press, 2019). Sert Avrupa şüpheciliği, AB ve Avrupa entegrasyonuna ilkesel olarak bir karşıtlık anlamına gelmektedir. $\mathrm{Bu}$ görüştekiler, ülkelerinin üyelikten ayrılması gerektiğini savunmaktadırlar, hatta AB'nin varllğına karşıdırlar. Birleşik Krallık Bağımsızlık Partisi (UKIP), sert Avrupa şüphecisi partilerin en önemli örneği olarak gösterilmektedir. Yumuşak Avrupa şüpheciliği ise, AB ve Avrupa entegrasyonuna ilkesel olarak karşıtlı içermeyen, $A B$ üyeliğini ve $A B$ 'nin mevcudiyetini destekleyen reformist bir görüştür. Bu görüştekiler, "ulusal çıkarların” AB'nin yönergeleri ile uyumlu olmadığ1 düşüncesinden yola çıkarak bazı politikalar konusunda endişelerini dile getirmektedirler. BK'deki Muhafazakar Parti bu görüşü temsil eden önemli bir örnek olarak gösterilebilir (Taggart ve Szczerbiak, 2002, s. 7; Ultan ve Ornek, 2015, s. 50-51).

BK'nin, küresel düzeyde bağlantıları ve İngiliz Devletler Topluluğu ile ilişkileri konusundaki muhafazakar tutum, Birlik'in ilk yılarında üyeliğe karşı muhalefete ilk zemini hazırlamıştır. Bu muhafazakâr yaklaşım; Thatcher'in 80'li yıllarda Tek Pazar'ı destekleyen AB içindeki neo-liberal politikaları savunan, diğer yandan $\mathrm{AB}$ içinde parasal birlik ve sosyal politikalar yoluyla entegrasyonun yayılmasına karşı çıan tavrından güç almış; Maastricht anlaşmasıyla ortaya çıkan bölünmeler ile yakın zamanda daha popülist bir Avrupa şüpheciliğine dönüşmüştür (Bulmer ve Quaglia, 2018, s. 1091).

BK için AB'ye üyelik, beraberinde göçmen sorununu getirmektedir. Almanya, BK, Fransa, İspanya ve İtalya; 41 milyon göçmene ev sahipliği yapmaktadır. Geriye kalan diğer Avrupa ülkeleri ise 35 milyon göçmene ev sahipliği yapmaktadırlar (Çenberci ve Gövdere, 2017, s. 1434). Özellikle Doğu Avrupa ülkelerinin Birlik'e katılımılla, BK'ye gerçekleşen göç miktarı artmıştır (Kılcı, 2018, s. 20).

BK'de göçmen karşıtllğ̆ konusunda en radikal çizgide bulunan ve söylemleri ırkçı bir nitelik taşıyan UKIP'nin, 2015 seçimlerinde yüzde 13 oy alması, BK'de yabanc1 karşıtlı̆̆ının yükseldiği şeklinde değerlendirilmiştir. Brexit referandumu kampanyasında UKIP, BK'nin yabancı işgali altında olduğu söylemini sürdürmüştür (Başkan, 2019).

Brexit referandumu ve ırkçı sonuçlarının görünen sebebi, "İngilizlik" politizasyonudur. Ayrılma yönündeki kampanyalar birbirine zıt ancak birbiriyle bağlantılı iki görüşü bir araya getirerek zafer kazanmıştır. Bunlardan biri emperyal bir özlemle Britanya’nın dünyadaki yerini restore etmektir. Diğeri Britanya'nın neo-liberal dönemde içine girdiği yapısal düşüşten kaynaklanan, aşağı yönlü hareketliliğin yanı sıra, çalışan sınıfın zarar görmesindeki sürekliliğinin yarattığı, ulusalcı bir kırgınlık politikasıdır. Çalışan sınıfın yenilgisinden önemli bir uyanışla yola çıkarak, İngilizlik; ırkçılaşma ve dar milliyetçilik ile yeniden ortaya çıkmış, Brexit sayesinde kendine ifade yolu bulmuştur (Virdee ve McGeever, 2018, s. 1802-1804).

BK'yi AB'den ayrılmaya iten bir diğer neden, İngiliz aydınları arasında artan "BK, Avrupa'ya mı aittir yoksa Atlantik ülkesi midir?" tartışması (Aybar, 2016) ve diğer ülkelerde akıllarda karışıklık yaratan "BK'nin Avrupalıllğı" dır. BK; Euro'nun esneklik, uyumlaşma, işsizliğin ve yatırımların finansal piyasalar üzerinde olumlu etkisi olmadığ1 müddetçe (Sefer, 2014, s. 49, 84) AB ile ortak para birimi konusunda Euro alanı ve Schengen bölgesi gibi bazı politikaların dışında kalacağını (opt-out) ifade etmiştir (İktisadi Kalkınma Vakfi, 2018, s. 70).

BK'nin karşılaştığı dış politika sorunları, AB'den ayrılma sürecini etkilemiştir. Hazırlıksız olduğu bir dönemde karşılaştı̆̆ Arap Baharı, Mısır ve Tunus'ta yaşanan gelişmeler ve Libya Krizi (Sefer, 2014, s. 90) BK Hükümetini hazırlıksız yakalamış, Körfez odaklı ve ekonomi güdümlü dış politikasını AB ile uyumlu hale getirmeye itmiştir (Küçükkeleş, 2013, s. 16).

BK'nin AB'den ayrılması sürecinin bir diğer nedeni, AB'ye duyulan güvenin azalmasıdır. Birlik'in küresel ekonomideki öneminin azalması, 2008 dünya krizi yüzünden kırılgan ekonomilerin gerilemesi (Alaca, 2017, s. 275) ve gelişmekte olan ülkelerin ekonomik büyüme oranlarının azalması, BK'nin ikili ticaret anlaşmaları yapmasının önünü kapatmışır (Aybar, 2016). Aynı zamanda AB'nin üretim düzeyinin 
düşmesi dolayısıyla Almanya’ya bağımlı bir üretimin gerçekleşmesi de BK'yi rahatsız ederek ayrillğa sürüklemiştir (Tüysüzoğlu, 2013).

BK'nin AB bütçesine yaptı̆̆ katkı, ulusal çıkarlar çerçevesinde tartışma yaratmış; BK, Thatcher'in sert yaklaşımıla 1984'te kalıcı olarak iskonto hakkı kazanmıştır. Bu hakka göre $\mathrm{BK}$, AB bütçesine yaptığı katkı ile bütçeden aldığı tutar arasındaki farkın \% 66’sını geri almaktadır. Buna rağmen $\mathrm{BK}$, AB bütçesine net katkıda bulunan üye devletler arasında 3. sırada yer almaktadır (Aykın, 2017)

Brexit referandumunda; bölgesel düzeyde üretim, eğitim ve yaşlı nüfus oranının, göçmenler ve $A B$ konusundaki tutumu etkilediği görülmektedir. Kişi başına GSYİH'nin ve eğitimin düşük, 65 yaş üzeri nüfus yoğunluğunun ve net göç miktarının yüksek olduğu bölgelerde bireyler $A B$ konusunda daha kayg1ılıı, göçmen komşu istememektedir ve Brexit referandumunda ayrılma yönünde oy kullanmıştır. Ayrıca göçmenler ve AB genişlemesi konusunda olumsuz tutumlar, Brexit referandumunda ayrilık yönünde oy kullanma davranışı ile ilişkilidir (Arnorsson ve Zoega, 2018, s. 301).

Brexit referandumunda ayrılma seçeneğinin, ekonomik küreselleşmenin daha güçlü gerçekleştiği bölgelerde daha yüksek çıktığı görülmektedir. Colantone ve Stanig (2018, s. 201) seçmenin oy verme davranışının sosyotropik bir nitelik taşıdığını, kendi bireysel durumlarından bağımsız olarak, bölgenin genel ekonomik durumunu dikkate alarak oy verdiklerini değerlendirmektedir.

\section{Süreç Nasıl İşleyecek?}

Üyeliğinin ilk gününden bugüne dek tam bir üye gibi davranmayan BK'nin, AB ile ilişkisi daima iç tartışma konusu olmuştur (House Of Lords, 2016: 5). Ülke içerisinde AB’ye destek verenlerin yanı sıra karşı olanların da varllı̆ı söz konusu olduğundan Birlik'te kalıp kalmama konusunda zaman zaman referanduma gidilmiştir. Bu konudaki ilk referandum ülkenin 1973’te üyeliğe katılmasından sadece iki yll sonra $1975^{\prime}$ te yapılmış ve \% 64'lük bir katıllımla ve \% 67'lik bir oran ile Birlik'te kalınması yönünde sonuçlanmıştır (Miller, 2015, s. 25).

23 Haziran 2016 yllinda Brexit olarak isimlendirilen ikinci referandum gerçekleştirilmiştir. Referandum sonuçları hem İngiliz Hükümetini hem de Avrupa siyasetini derinden sarsacak bir etki yaratmıştır. \% 72,2 katılım ile gerçekleşen referandumda seçmenlerin \%51,9’u Birlik'ten ayrılma yönünde oy kullanırken; \% 48,1'i ise Birlik'te kalma yönünde oy kullanmıştır. Başbakan Cameron bunu bir yenilgi olarak nitelendirerek istifa etmiştir. Mart 2017'de Başbakan May, BK'nin AB'den resmi olarak ayrllkk müzakerelerini başlatacak süreci $\mathrm{AB}$ Anayasası'nın 50. Maddesi'ne dayanarak yürürlüğe koymuştur (Bulmer ve Quaglia, 2018, s. 1089).

Brexit süreci, AB Anayasası'nın 50. Maddesi uyarınca karşıllklı müzakerelerle ilerleyecektir (Karacan, 2017: 404). Bu süreçte $B K A B$ hukukunda söz sahibi olacaktır ancak Birlik'in gelecekteki karar alma süreçlerinde bir yetkisi olmayacaktır. BK çekilme sözleşmesinin yürürlüğe gireceği tarihe kadar $A B$ hukuk hak ve yükümlülüklerine bağlı kalacaktır (Birch, 2016). Tüm bunların yanı sıra Brüksel'de yapılan AB Genel İşler Konseyi Toplantısı'nda “BK 2021'den önce AB'li ortaklarından izin almaksızın herhangi bir üçüncü tarafla ticari anlaşma imzalayamayacak” kararı alınmıştır. Geçiş sürecinin 31 Aralık 2020'de sona ermesine karar verilmiştir (“AB, Brexit’te Geçiş Sürecini Belirledi,” 2018).

BK'de yaklaşık 19 bin AB yasası uygulanmaktadır. Ayrılık kararının verilmesiyle birlikte yürütülecek olan 2 ylllık müzakere sürecinde 19 bin yasanın tümümün değiştirilmesi mümkün olmadığından ilk olarak belli başlı düzenlemelere gidilecektir (“İngiltere Ulusal Kanunlarına Dönüyor," 2017).

\section{Brexit Müzakereleri}

BK'nin AB üyeliğinden ayrılması yönündeki müzakereler 19 Haziran 2017 tarihi itibariyle başlamış ve müzakerelerin ilk turu dört gün sürmüştür ("Brexit Müzakereleri Bugün Başliyor," 2017). AB, müzakereler başlamadan önce görüşmelerin "geri çekilme-ilişkilerin geleceği-geçiş dönemi" olmak üzere üç aşamada ve sıralı bir şekilde gerçekleşmesini önerirken; BK ise tüm bu aşamaların paralel bir şekilde yürütülmesini önermiştir (Köker, 2017). Haziran 2017'de tamamlanan müzakerelerin ilk turunda, bahsi geçen öneriler göz önünde tutularak, görüşmelerin AB'nin önerdiği şekilde-sıralı biçimde yapılacağı kararına varılmıştır.

Müzakerelerin ilk etabında, vatandaş hakları, ayrillğın mali boyutları ve "Kuzey Irlanda-İrlanda Cumburiyeti sinır 'gevşek' olacak" ("İngiltere ve AB, Brexit Müzakerelerinde İkinci Aşamaya Geçiyor,” 2017) gibi sınırlarla ilgili diğer meseleler özellikle ele alınan ve bir karara bağlanan hususlar olmuştur (Köker, 2017). Bu aşamada anlaşmaya varılan bir diğer husus ise BK'nin AB'den ayrllık için ödeyeceği tazminatın 
("Brexit Müzakerelerinde İkinci Aşama," 2017) en az 35 milyar Sterlin olmasıdır (“İngiltere ve AB, Brexit Müzakerelerinde İkinci Aşamaya Geçiyor,” 2017).

Brüksel'de yapılan bu toplantıda Brexit müzakerelerinde ikinci aşamaya geçilmesi kararı alınmış ve gelecek etapta BK ile AB'nin ilişkilerinin gelecekte nasıl işleyeceği ele alınmıştır. Avrupa Komisyonu başkanı Jean-Claude Juncker ikinci aşamanın oldukça zor geçeceğine vurgu yapmış ve anlaşmaların artık resmiyete dönüşmesi gerektiğini belirtmiştir. May bu öneriyi memnuniyetle karşılamış ve BK'nin AB ile olan ilişkilerini şekillendirecek olan müzakerelerin ikinci aşamasına her iki tarafın da "yaratıcı ve az̧imli yaklaşmasmi” talep etmiştir (“İngiltere ve AB, Brexit Müzakerelerinde İkinci Aşamaya Geçiyor,” 2017).

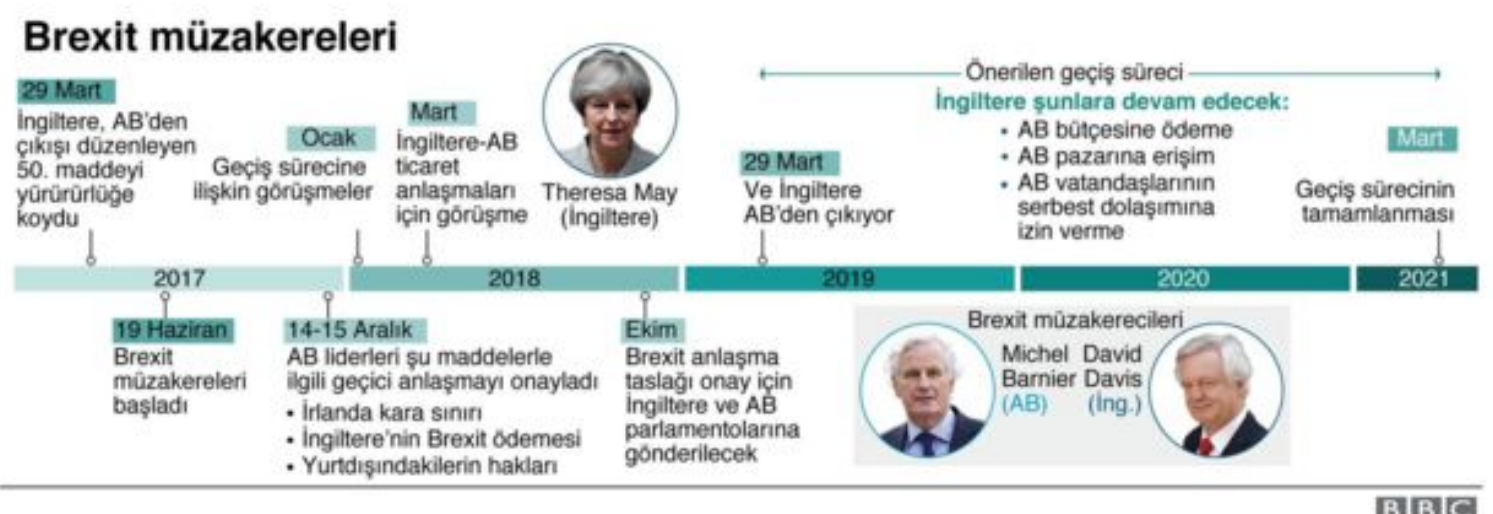

Sekil 1. Brexit Müzakereleri ("Ingiltere ve AB, Brexit Müzakerelerinde İkinci Așamaya Geçiyor," 2017).

$A B$, müzakerelerin ikinci aşamasına yönelik bir yönetmelik hazırlamış ve BK'den, geçiş süreci boyunca Avrupa Adalet Divanı'nın kararlarını kabul etmesini ve serbest dolaşımlara izin vermesini talep etmiştir. Ayrıca AB, BK'den AB ile olan ilişkilerinde geleceğe yönelik pozisyonlarına açıklık getirmesini talep etmiştir (“İngiltere ve AB, Brexit Müzakerelerinde İkinci Aşamaya Geçiyor,” 2017).

Müzakerelerin ikinci aşaması için BK ve AB Heyeti 6-8 Şubat 2018'de bir araya gelmişlerdir. Burada müzakerelerin ağırlık noktası olarak, AB Konseyinin onay vermiş olduğu Geçiş Dönemi Müzakereleri Çerçeve Belgesi uyarınca geçiş dönemine ilişskin düzenlemeler ele alınmıştır. AB'den ayrıllı̆̆ı 29 Mart 2019'dan itibaren başlaması ve geçiş döneminin 31 Aralık 2020 tarihinde son bulması kararlaştırılmıştır (Elbir, 2018, s. 2).

Ancak BK Parlamentosu, AB ile üzerinde uzlaşılan anlaşmayı 3 kez red etmiştir. Bu sebeple BK, henüz $A B$ 'den ayrılmamıştır. $B K, A B$ 'den iki kez erteleme talep etmiştir. $A B$ tarafindan $B K$ 'ye verilen yeni ayrilık tarihi 31 Ekim 2019'dur. Brexit sürecini tamamlayamayan BK Başbakanı May, Muhafazakar Parti'nin liderliğinden ayrılmıstır, yeni parti liderinin Temmuz 2019'da belirlenmesi beklenmektedir. Süreç hala belirsizliğini korumaktadır. Muhafazakar Parti başkanlığına aday liderlerin, Brexit sürecinin nasıl tamamlanması gerektiği konusunda tavrı farklılık göstermektedir. Bazı adaylar anlaşmasız bir ayrllıkta sorun görmediklerini belirtirken, bazıları anlaşmayı tekrar müzakere etmenin yolunu arayacaklarını ifade etmektedir. Yeni bir referandumun veya genel seçimin söz konusu olabileceği de seçenekler arasında değerlendirilmektedir. Muhafazakar Parti'nin yeni başkanının kim olacağı, ayrılma şartlarını da belirleyecektir (Barnes, 2019).

\section{Brexit'in Birleşik Krallık'a Etkisi}

Brexit’in BK ekonomisi üzerinde yaratacağı etkileri konu alan ilk çalışmaların çok karamsar bir tablo ortaya koyduğu görülmektedir. Ancak sürecin üçüncü yllı itibariyle gerçekleşen sonuçların, beklenen sonuçlar kadar keskin olumsuz bir çizgide olmadığ1 söylenebilir. Ekonomik etkiler konusunda gerçekleştirilen akademik çalışmaların, Brexit sürecindeki bölünmüşlüğün izlerini taşıyor olması dikkat çekicidir. BK'nin AB'den ayrılması durumunda zarar etmesinin kaçınılmaz olduğu, ancak bu zararın şiddetinin $\mathrm{AB}$ ile ayrılık sürecinin şartlarına bağlı olarak değişebileceği, pek çok ekonomist tarafından dile getirilmektedir (Chang, 2018, s. 2349). Diğer yandan, ayrılma sürecinde BK'nin şiddetli bir ekonomik bunalıma gireceği ve mutlak olarak zarar edeceği söylemine dayanak olarak gösterilen ekonomik analizlerin uygun yönteme dayanmadığını ileri süren ayrılma taraftarı ekonomistler; AB'nin bir başarı öyküsü olmadığını ve kısa süreli olumsuzluklar yaşansa bile BK'nin bu ayrılıktan kesinlikle kazançlı çıkacağını savunmaktadır (Minford, 2019; Bootle vd., 2018). 
2017 Eurostat verilerine göre, BK 2,3 trilyon Euro GSYIH ile, AB'nin Almanya'dan sonraki ikinci büyük ekonomisidir. GSYIH 2016 yllında \% 8, 2017 yllında ise \% 3 azalmıştır. Brexit referandumu sonucunda AB'den ayrılık kararının alınmasıyla birlikte Sterlin ABD Doları karşısında 1985 yılından sonraki en düşük seviyeye düşmüştür. Sterlin'in yaşadığı değer kaybı, ithalatın pahalılaşmasına, enflasyonun artmasına sebep olmuş; ancak ihracatçılar için firsat yaratmıştır (İktisadi Kalkınma Vakfı, 2018, s. 52, 55). Sterlin/Euro paritesi, 2013'ten sonraki en düşük seviyeyi görmüş, 1,17 seviyesine düşmüştür. Sterlin'deki değer kaybı, BK'nin milli gelirinin geçerli parite üzerinden Fransa'nın gerisine düşmesine sebep olmuştur ("Brexit: İngiltere Artık En Büyük 5. Ekonomi Değil," 2016). BK ekonomisi dünya sıralamasında gerilere düşerek en büyük 5. ekonomi konumunu kaybetmiştir (Petroff, 2017).

BK Merkez Bankası (BoE), telafi edici önlemler aldığı için, BK'nin ekonomik bunalıma sürükleneceği tahminleri doğru çıkmamıștır. 2016 Ağustos ayında faiz oranları \% 0,50'den \% 0,25’e indirilmiș, 2009 yllından sonra borçlanma maliyetlerinde ilk düşüş gerçekleşmiştir (İktisadi Kalkınma Vakfi, 2018, s. 55).

BK, büyük bölgelerarası gelişmişlik farklılıklarının bulunduğu bir ülkedir. Londra ve hinterlandı büyürken, Midlands, İngiltere'nin kuzeyi, Kuzey İrlanda ve Galler; Orta ve Doğu Avrupa'daki yoksul bölgeler ile daha çok ortak özelliğe sahiptir. Brexit sonrası süreçte, özellikle uzun dönemde, ülkedeki bu dengesiz ekonomik gelişmişlik farklılığın artacağı beklenmektedir (Carter ve Swinney, 2019).

Brexit referandumu BK'de, coğrafi ve siyasi bölünmüşlüğün önünü daha çok açmıştır. 2014'te İskoçya'da gerçekleştirilen bağımsızlık referandumunda, İskoçya, AB üyeliği içinde kalmak amacıyla BK'ye bağlılık tazelemiştir. Ancak Brexit sonrası süreçte, İskoçya Başbakanı Nicola Sturgeon, \% 62 oy oranıyla $\mathrm{AB}$ üyeliğinin devamı yönünde oy veren İskoçya'nın, yeni bir bağımsızlık referandumuna gidebileceğini ifade etmiştir. Kuzey İrlanda'da da benzer ayrılıkçı hareketlerin artabileceği düşünülmektedir (Başkan, 2016).

Mali Çalışmalar Enstitüsü (Institute for Fiscal Studies - IFS) BK'nin Birlik’ten ayrıldıktan sonraki 2 yıl içerisinde kemer sıkma politikalarını uygulamaya mecbur kalacağı bir süreç geçireceğini öngörmüş ve Sterlinin uluslararası rezerv para birimi olma özeliğini kaybedebileceğini belirtmiştir. Uluslararası kredi derecelendirme kuruluşu Standard \& Poor's (S\&P) da BK'nin AB'den ayrilmasının, 2019-2020 dönemine kadar kamu finansmanına 20 ile 40 milyar Sterlin arasında bir maliyetinin olabileceğini belirtmiştir (“İngiltere AB'den Ayrıldı! Peki Şimdi Ne Olacak?," 2016). Aynı zamanda AB'den ayrılmanın hane halkına maliyetinin yıllık 2.200 Sterlin olabileceği, gelecek 10 yıl içerisinde ise Sterlin'in değerinde \%10’luk kayıplar yaşanabileceği tahmin edilmektedir (Aydemir, 2016).

Ayrılık kararının alınmasının ardından BK'nin AB'ye ihracatı, BK Ulusal İstatistik Ofisi (ONS) Raporu'na göre 2000 yllında \% 54 iken 2016 itibariyle (mal ihracat1 \% 48, hizmet ihracat1 \% 37) \% 43'e düşmüştür (Office for National Statistic, 2018).

BK içinde Brexit’ten en çok etkilenmesi beklenen sektörler; bankacılık, varlık yönetimi, sigortacılık ve finansal hizmetlerdir. 2016 yllinda BK'de finans ve sigortacilık hizmetleri 124,2 milyar Sterlin ile gayr1 safi katma değerin \% 7,2'sini üretmiştir. Bu sektörlerde çalışan sayısı 1,1 milyondur. Londra'da 250'den fazla yabancı banka faaliyet göstermektedir ve Londra, en yakın rakipleri olan New York, Paris ve Frankfurt'tan bu açıdan öndedir. Dünyadaki bankacılık işlemlerinin yaklaşık beşte biri BK'de gerçekleştirilmektedir. Tek başına Londra, 61,7 milyar Sterlin büyüklüğünde finans ve sigortacılık pazarına sahiptir (İktisadi Kalkınma Vakfi, 2018, s. 56).

$\mathrm{AB}$ mevzuatına göre, bir finans kuruluşunun merkezinin Birlik içindeki herhangi bir ülkede yer alması durumunda, finans kuruluşu Birlik içindeki diğer ülkelerde faaliyetlerini sürdürebilmektedir. BK'nin AB'den ayrrllğının gerçekleşmesi durumunda BK'de merkezi bulunan finans kuruluşları, $\mathrm{AB}$ içindeki ülkelerde faaliyet gösterebilmek için her bir ülkeden ayrı ayrı yetki belgesi almak zorunda kalacaktır. Brexit sürecinin getirdiği belirsizlik, Londra'daki finans kuruluşlarını, yeni merkez arayışlarına yöneltmiştir. Londra'nın finans merkezi statüsünün, bu açıdan risk altında olduğu değerlendirilmektedir (İktisadi Kalkınma Vakfi, 2018: 57).

AB'den ayrllık kararının alınmasının ardından, 2016 yılı verilerine göre BK'de işsizlik oranı son 11 yllın en düşük seviyelerine gerileyerek \% 5,6'dan \% 4,9'a düşmüştür (Office for National Statistic, 2016, s. 3). Ancak rakamların, BK'nin Birlik'ten ayrılmadan önceki süreyi kapsadığı dikkate alınmalıdır ve bu olumlu seyrin ilerleyen y1llarda devam etmesinin olası olmadığ öngörülmektedir ("UK Unemployment Rate Falls to Fresh 11-Year Low," 2016). BK Merkez Bankası (BoE) ise gelecekteki iki yıl içerisinde işsizlik 
oranının \% 5 ile \% 6 arasında olacağını tahmin etmektedir (“İngiltere: İşsizlik Son Çeyrekte Düştü Ancak Brexit İstihdam İçin Endişe Kaynağ1,” 2016).

AB'nin genişlemesi süreciyle yeni üye olan ülkelerden BK’ye gelen göçmenlerin ve Türkiye gibi henüz tam üye statüsüne geçmemiş ülkelerden gerçekleşmesi beklenen göçlerin, Brexit sürecinde ayrılma yönünde kampanya yürüten partiler tarafından kullanılmış olması, BK'de yabancı karş̧ıtlı̆ı̆ın yükseldiği şeklinde yorumlanmıştır. Brexit referandumu sonrasında gelen ayrılma kararı, ülkedeki göçmenler için, AB'nin sunduğu temel hak ve özgürlükler ve ayrımcilı̆̆n önlenmesi konusundaki yasal çerçeveden çıkış anlamına gelmektedir. Bu bağlamda ülkede yaşayan yabancıların; BK'nin, AB üyeliğinden ayrıldıktan sonra daha dışarıya kapalı bir ülkeye dönüşeceği, iş ve eğitim imkanlarını kaybedebilecekleri yönünde kaygılar duydukları görülmektedir. Ayrıca Brexit sürecinde, kampanyalarda kullanılan politik söyleme paralel olarak, ırkçı saldırılarda artış meydana gelmiştir (Başkan, 2019). Referandum sonucunun açıklanmasından sonraki ilk dört hafta içerisinde 6.000 nefret suçu rapor edilmiştir (Komaromi, 2016). Ancak BK'deki AngloSakson laiklik geleneği, devletin ve dinin birbirine müdahale etmemesi üzerine kuruludur; Brexit sonrasi süreçte de göçmenlerin hayatını değiştirecek nitelikte kısıtlayıcı yasal düzenlemelerin yapılmasına olanak vermeyeceği değerlendirilmektedir (Başkan, 2019).

\section{Brexit'in AB'ye Etkileri}

BK'nin Birlik'ten ayrılma kararını vermesiyle $\mathrm{BK}$ ve $\mathrm{AB}$ derin bir belirsizliğe düşmüştür. $\mathrm{Bu}$ kararın $\mathrm{AB}$ için kırılma noktası olduğu ifade edilebilir. BK'nin ayrılmasından dolayı $\mathrm{AB}$ bütçesinde yaklaşı 13 milyar Euro'luk bir açık ortaya çıkması beklenmektedir. Bütçe açığını diğer üye ülkelerin gidermesi gerekecek, harcamaları olumsuz yönde etkilenecektir (Çetin ve Hatip, 2018).

OECD, 2020'de AB GSYİH'nın \% 1 oranında; 2030'da ise \% 0,10 - \% 0,58 oranında düşeceğini öngörmektedir. Bu tahminler, AB'nin 80 milyar Euro'luk bir kayıp yaşayacağı anlamına gelmektedir (Velthuijsen vd. 2018, s. 6).

AB üye ülkelerinin bankacılık aktivitelerini kendi ülkelerine kaydırma ihtimalleri, Birlik açısından, finansal hizmetlerin maliyetini ve likiditeyi etkileyecektir (İktisadi Kalkınma Vakfi, 2018: 56-57). Finansal istikrarın bozulmasıyla ayrılık öncesi $\mathrm{AB}$ ülkeleriyle yapmış olduğu \% 55 oranındaki dış ticaret değerlerinin ayrllık sonrası \% 90'lara varan oranlarla düşeceği ifade edilmektedir ve bu durum AB için büyük bir ticaret kaybının olacağı anlamına gelmektedir (Aydemir, 2016). Ticaretin bu denli etkilenmesi \% 2,5 olan küresel ekonomik büyüme beklentisini olumsuz etkileyerek dünya ekonomisinde büyümeyi yavaşlatacaktır. Dünya ekonomisindeki yavaşlama beklentisi, petrol ve emtia fiyatlarının gerilemesine neden olacaktır. Küresel mali piyasalarda mali varlık fiyatları, $\mathrm{AB}$ öncelikli olarak düşmekte ve güvensizlik kendini göstermektedir. Böylece güvenli varlıklara hızlı bir sermaye kaçısı yaşanmakta ve gelişen ülkelerden de sermaye çıkışları olmaktadır. Güvenli liman arayan altın, İsviçre Frang1, Japon Yeni ve gelişmiş ülke tahvilleri değer kazanmaktadır. Ortaya çıkan bu istikrarsızlıkla baş edebilmek için BK ve Avrupa Merkez Bankaları ile gelişmiş ülkelerin merkez bankaları ortaklaşa hareket etme kararı almışlardır (Gürlesel, 2016, s. 99-100).

BK'nin ayrılışıyla Birlik içerisinde Fransa ve Almanya'nın ağırlığı artacaktır. Ancak son zamanlarda Fransa'nın ekonomik olarak zayıflaması Almanya'yı ön plana çıarmışıı. Böylelikle Almanya'nın Birlik içerisinde hakimiyetinin artması muhtemeldir ve bu durum $A B$ 'de bir gerilime neden olacaktır. Diğer yandan, BK'nin AB'den ayrılmasıyla $\mathrm{AB}$ genelinde yabancı karşıtı milliyetçi popülist partilerin güçlenmesi ve AB'nin bütünleşme sürecinin yavaşlaması söz konusu olabilir (Eralp, 2016, s. 2-3).

$A B$, sürecin getirdiği belirsizliği ortadan kaldıracak adımlar atmazsa ortaya çıkacak olan siyasi ve ekonomik zedelenmeler gittikçe ağırlaşacaktır. Belirsizlik, yeni ayr1lık taleplerini ortaya çıkarabilir. Böyle bir durumda $\mathrm{AB}$ kendi içerisinde hızlıca yapılandırmaya gitmesi ve daha esnek bir entegrasyon modeli uygulaması beklenmektedir (Gürlesel, 2016, s. 99).

Salvatore (2017, s. 836) Avrupa'nın büyüme sorununu yapısal nedenleriyle analiz eden çalışmasında, Avrupa'nın bu sorunun üstesinden gelmek için uyguladığı politikaları değerlendirmiş ve uygun politikalar uygulansa bile, özellikle Brexit ve dünya ekonomisindeki genel yavaşlama nedeniyle, Avrupa'da büyümeyi hızlandırmanın zor olacağı sonucuna ulaşmıştır.

\section{Brexit'in Türkiye'ye Etkileri}


BK'nin AB'den ayrılması Türkiye'yi doğrudan etkileyecektir. Türkiye'nin AB'ye tam üyeliği konusunda önemli bir destekçisini kaybedeceği sıklıkla ifade edilmektedir (Gürlesel, 2016, s. 100). Ancak, resmi olarak Türkiye'nin $\mathrm{AB}$ üyeliğini destekleyen $\mathrm{BK}$ 'nin, pratikte ne kadar destekçi olduğu tartışmalıdır. Brexit sürecinde yürütülen kampanyalarda Cameron, Türkiye'nin $\mathrm{AB}$ üyeliği konusunda dile getirilen endişelere, Türkiye'nin 3.000 yılına kadar $\mathrm{AB}$ üyesi olamayacağı cevabını vermiştir (İktisadi Kalkınma Vakfi, 2018, s. 72). Diğer yandan, Türkiye için önemli bir aşama olan Türkiye'nin AB'ye katılım müzakerelerinin başlatılması kararı, $\mathrm{BK}$ 'nin $\mathrm{AB}$ dönem başkanlığını yaptığı dönemde alınmıştır (T.C. Londra Büyükelçiliği Ticaret Müşavirliği, 2010, s. 30).

BK ile Türkiye arasındaki ikili ticaret incelendiğinde, Türkiye'de en fazla yabancı yatırımı bulunan ülkenin BK olduğu görülmektedir. Bu bağlamda Türkiye'de 2900'den fazla İngiliz sermayeli şirket bulunmakta ve bu yatırımların toplamı yaklaşık olarak 9 milyar 538 milyon ABD Doları olduğu bilinmektedir (T.C. Dışsişleri Bakanlığı, 2018a).

2001 yllindan bu yana ikili arasındaki ticaret dengesi Türkiye lehine ilerlemiş ve son 10 yllda \% $\% 8,8$ oranında artmıştır. Türkiye, 2001 yılından beri BK ile diş ticaretinde fazla vermektedir. 2015 ylında bir önceki ylla göre \% 5,6 oranında bir artış yaşanarak 17 milyar 8 milyon ABD Doları olmuştur. Böylece BK bu dönemde Türkiye'nin ithalat yaptığı ülkeler arasında 11. sirada yer alırken; ihracat yaptığı ülkeler arasında ise 2. sırada yer almışır. Ancak 2017 verileri ele alındığında, ylın ilk çeyreğinde bir önceki ylın aynı dönemine kıyasla BK'ye gerçekleştirilen ihracat \% 14 oranında daralmış, en çok ihracat gerçekleştirdiğimiz ülkeler sıralamasında 4. sıraya gerilemiştir. (T.C. Dışişleri Bakanlığı, 2018a).

BK'de AB'den ayrılmaya yönelik yürütülen kampanyalarda Türkiye'nin AB üyeliğinin "tehdit" niteliğinde tanımlanarak kampanya malzemesi olarak kullanılmasının, Türkiye'nin uluslararası platformlarda saygınlığını zedeleyebileceği yönünde değerlendirmeler bulunmaktadır (Uzunluoz, 2018). BK'nin AB'den ayrılmaması durumda Müslüman göçmen akımına uğrayacağı ve radikal İslamcı bir tehditle yüzleşeceği gibi ifadeler kampanyalarda sık sık dile getirilmiştir (Aras ve Gunar, 2017, s. 307). Aralarında BBC'nin de bulunduğu yurtdısında pek çok yayın organının; Türkiye'de 15 Temmuz 2016'da gerçekleştirilen darbe girişiminin, "Türkiye için umut vaat eden reformist Müslümanlar" tarafindan gerçekleştirildiği yönündeki haberleri, Türkiye'deki siyasal gelişmeleri doğru okumadıklarını göstermektedir (Başkan, 2017, s. 112-114).

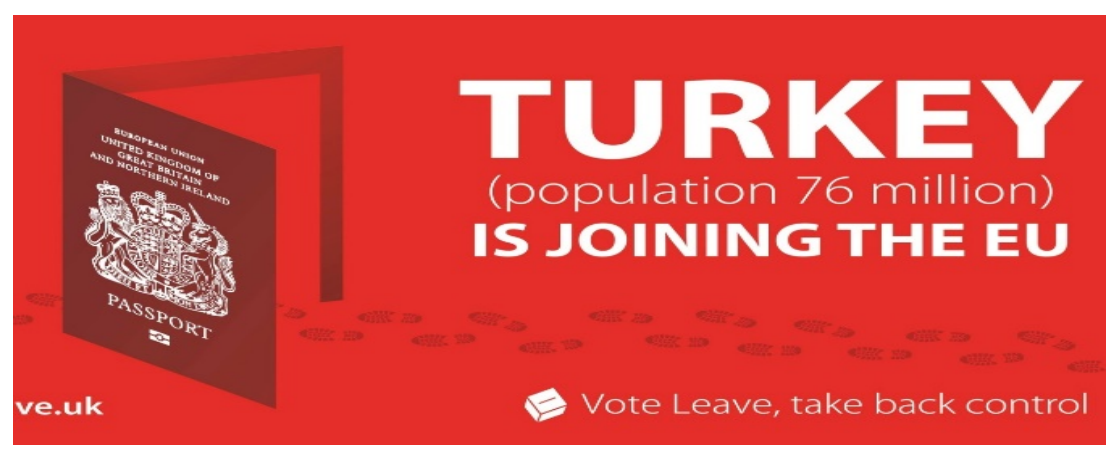

Şekil 2. BK'de Referandum Öncesi Ayrlliğ Destekleyenler Tarafindan
Kullanılan Türkiye Afisi (Cookman, 2016).

Diğer yandan Türkiye'de $\mathrm{AB}$ üyeliği, sıklıkla iç siyaset malzemesi olarak kullanılmakta, partiler iktidarda ve muhalefette oldukları dönemlerde birbirine zıt yönde tavır takınmaktadırlar (Başkan, 2011: 166). Brexit sürecinde, Türkiye'nin $A B$ üyeliğinin, benzer şekilde, $B K$ 'de iç siyaset malzemesi haline geldiği görülmektedir. Muhafazakar Parti başkan adayı Boris Johnson, geçmişte destek verdiği Türkiye’nin AB üyeliğine bugünlerde karşı bir tutum göstermektedir ("The Conservative Leadership Which Boris Would Britain Get?", 2019).

Dünyanın en büyük finans merkezi olan Londra (İstanbul International Finance Center, 2018) Türkiye'nin en büyük borçlanma kaynağıdır. Ayrılık sonrası Londra finans merkezinde yaşanan gelişmeler Türkiye'yi yakından etkileyecektir (Gürlesel, 2016, s. 99).

BK'nin AB'den ayrılmasıyla ülke içerisinde açığa çıkan işsizlik ve ekonomik istikrarsızlık, vatandaşlarının turizm tercihlerini etkilemisstir. Ayrllıktan sonra Türkiye ile olan turizm ilişkilerinde olumlu yönde bir artış beklenmektedir. Sterlin'in Euro karşısında değer kaybetmesi nedeniyle turizm tercihlerinin AB dışı ülkelere doğru kayacağı beklentisi doğmuştur. 2016 yılı Eylül ayında BK'de Türkiye'ye yaz sezonu 
için 81.699 kişi erken rezervasyon yaptırırken; 2017 ylı itibariyle 2018 yaz sezonu için bu sayı \% 79 oranında artış göstererek 145.846 kişiye ulaşmıştır (Türkiye Otelciler Birliği, 2017, s. 13).

\section{Brexit'in AB Üyesi Ülkelere Etkilerini İnceleyen Çalışmalar}

Avrupa'nın en büyük ekonomisine sahip olan Almanya'nın Brexit'ten etkilenmesi kaçınılmazdır. Kolev, Matthes ve Busch, (2016) çalışmalarında, Almanya ile BK arasındaki ticari ilişkileri inceleyerek, Sterlin'in Euro karşısındaki \% 10'luk değer kaybı neticesinde, BK'nin Almanya'ya ihracatında \% 6, ithalatında ise \% 3,5 düşüş yaşadığı sonucuna ulaşmışlardır.

Alman Sanayi ve Ticaret Odası (Deutscher Industrie-und Handelskammertag, 2017) tarafindan yayınlanan çalışmada, Brexit’in, Alman şirketlerine etkisinin iş, yatırım ve ticaret açısından ezici şekilde olumsuz yönde olacağı sonucuna ulaşmıştır. Ayrılık henüz tamamlanmamış olsa da bu durumun ilk belirtileri, BK ile olan ticaretin azalmasıyla kendini göstermiştir. Brexit öncesi Almanya'nın üçüncü en büyük ihraç pazarı olan BK, 2017 itibariyle beşinci sıraya gerilemiştir. Araştırma sonuçlarına göre BK'de satın alma gücünün azalacağı beklentisiyle, BK'deki Alman şirketlerinin ekonomik durumunun kötüye gideceği öngörülmektedir. BK'deki her 12 Alman şirketinden biri yatırımlarını diğer pazarlara kaydırmayı planlamaktadır. Almanya'da özellikle otomotiv sektörünün Brexit’ten şiddetli şekilde etkilenmesi beklenmektedir (Deutscher Industrie-und Handelskammertag, 2017, s. 4).

BK, İrlanda'nın en yakın ekonomik ortaklarından biridir. Bu nedenle BK'nin AB'den ayrılmas1 doğrudan İrlanda ekonomisini de etkileyecektir. Bergin vd. (2017) İrlanda'nın Brexit tarafından özellikle olumsuz etkileneceği sonucuna ulaşmıştır. Barret vd. (2015) ise BK-AB arasındaki değişen ilişkiler nedeniyle İrlanda'nın etkileneceği konuları; mal ve hizmet ticareti, doğrudan yabancı sermaye yatırımları, enerji, göç ve işgücü piyasası olarak sıralamışır. Araştırma sonuçlarına göre, ticari ilişkilerde hem ihracat hem de ithalat ayrrlıktan olumsuz etkilenecektir. BK'den sınırlı da olsa İrlanda'ya doğru doğrudan yabanc1 yatırım sapması olabilir. Brexit ile İrlanda’ya gerçekleşecek göç sayısında da artış meydana gelecektir. BK'de yaşayan İrlandalı vatandaşlar başta olmak üzere birçok vatandaş, İrlanda'ya göç edecektir. Bu da İrlanda'da ücretleri düşürerek halkın refahını azaltacaktır.

Brexit’in Romanya ekonomisi üzerindeki etkilerini inceleyen Stanciu (2017) çalışmasında, etkilerin kısa vadede düşük, uzun vadede ise yüksek derecede olacağını ileri sürmektedir; ancak genel olarak ılımlı bir süreç geçirileceğini öngörmektedir. Brexit ile Romanya'nın maruz kalacağı olası ticaret zararları, kendini ilk olarak yatırım sektöründe gösterecektir. Çünkü Brexit, Romanya'nın 1,5 milyar ABD Doları yatırım yapan önemli bir ticaret ortağını kaybedeceği anlamına gelmektedir.

Brexit'in Romanya ekonomisi üzerindeki etkilerini inceleyen bir diğer çalşma ise Romanya Ticaret ve Sanayi Odası (CCIR) tarafından gerçekleştirilmiştir. CCIR, Stanciu (2017) ile aynı sonuçlara ulaşarak; Brexit'in Romanya dahil olmak üzere Orta ve Doğu Avrupa ülkeleri için bir firsat olabileceğini belirtmiştir. Çünkü BK'de faaliyet gösteren birçok sektör için bu ülkeler yeni pazar alanları olarak görülmektedir (The Chamber of Commerce and Industry of Romania, 2017, s. 4).

Benelüx ülkelerinin Brexit’ten ne derecede etkilendiğini inceleyen Ignáth (2017), 40 yilda oldukça güçlü hale gelen Belçika ile BK arasındaki dış ticaret ilişkilerinin Brexit’ten olumsuz etkileneceğini tahmin etmektedir. Özellikle diş ticaret, yatırımlar ve finans piyasaları ile bankacılık sistemi dikkat çeken alanlardır. BK'nin çıkışı ile kümülatif GSYİH'sinde \% 0,3-0,7 arasında değer kaybedeceği, böylelikle Brexit'in Belçika'ya maliyetinin 2,1 milyar Euro'ya mal olacağ1 öngörülmüştür. Belçika analistlerine göre, BK'de 12 bin işyerinin terk edilmesi nedeniyle işsizlik oranı $\%$ 8,7 olacaktır.

Velthuijsen ve Bernard'a (2016, s. 2) göre Euro ve Sterlin değerindeki artış BK-Hollanda ticaretini etkileyen önemli bir faktördür. Brexit’ten sonra özellikle çiçek ihracatında bir düşüş olduğu gözlemlenmiştir. Velthuijsen ve Bernard'ın çalışmasında Belçika'nın Brexit'ten büyük ölçüde etkileneceği belirtilmiştir.

BK Hollanda'nın üçüncü en büyük ticaret ortağıdır. Gerçekleştirilen ticaret Hollanda'daki toplam istihdamın yaklaşı1k \% 3,3'ünü ve nominal GSYIH'nin yaklaşık \% 3’ünü oluşturmaktadır. Hollanda hükümetinin yaptığı araştırmalara göre ülkenin nominal GSYİH'sinde Brexit nedeniyle \% 2-3 arasında düşüş yaşanacağı öngörülmektedir. Hollanda'nın doğrudan yabancı yatırımlarının \% 11'i BK'ye yöneliktir. Hollandalı firmaların BK'de yatırım miktarı 2015 yll sonu itibariyle 454 milyar Euro'dur. Ancak İngiliz Sterlini'nin değer kaybetmesi, BK'ye yapılan Hollanda ihracatına bir zarar olarak geri dönmektedir. Çünkü zayıf bir İngiliz Sterlini, BK'deki Hollandalı firmaların yatırım getirisini azaltmaktadır. Tüm bu olumsuz gelişmelerin yanı sıra Brexit'in Hollanda'ya faydası olduğu da söylenebilir. Avrupa pazarında faaliyet 
göstermeye devam etmek isteyen birçok banka, Brexit sonrası Amsterdam'a taşınacağını açıklamıştır (Lammersen, 2017). Bununla birlikte Brexit dolayısıyla Hollanda'da balıçılar tedirgin olmaktadır. Verimli bölge olduğu gerekçesiyle ağlarını İngiliz sularına atmayı tercih etmektedirler. Ancak Brexit sonrası İngiliz sularından çekilip Hollanda ve Almanya sularına yöneleceklerdir ("Brexit Hollandalı Balıkçları Endişelendiriyor," 2018).

Eluere ve Martin (2016)'e göre, AB'nin geri kalanı gibi Fransa da Brexit'ten önemli ölçüde etkilenecektir. İlk olarak iş ortamlarında bozulmalar yaşanacağı, Fransa GSYİH'nda düşüşler yaşanacağı ve orta vadede ihracatta ve yabancı ülkelerde yatırımın yavaşlamasıyla birlikte ekonomik büyümenin de olumsuz etkileneceği belirtilmiştir.

Chen vd. (2018) tarafindan Dünya Girdi-Çıktı Veri Tabanı (World Input-Output Database-WIOD) verileri kullanılarak gerçekleştirilen araştırmada, Brexit'in sonuçlarından hangi AB bölge ve ülkelerinin ticari olarak olumsuz yönde etkileneceği araştırılmıştır. Coğrafi olarak parçalanmış üretim süreçlerine uygun olarak tüm etkileri birleştiren bir indeks geliştirilmiştir. Şekil 3 ve 4'te araştırma sonuçlarının harita üzerinde gösterimi sunulmuştur. Araştırma sonuçları, BK'deki bölgelerin, diğer ülkelerdeki bölgelerden çok daha fazla etkileneceğini göstermektedir. İrlanda Cumhuriyeti'ndeki bölgelerde etki düzeyi; Londra ve kuzey İskoçya gibi en düşük etkiye maruz kalması beklen İngiliz bölgelerindekine benzer düzeylerdedir. Bunların dışında en çok etkilenecek bölgeler Almanya, Hollanda, Belçika ve Fransa'dır. AB bölgeleri içinde güney Almanya; Birleşik Krallık veya İrlanda'nın yarısı düzeyinde olmak üzere en yüksek risk taşıyan bölgedir. Ekonomik coğrafya açısından en kayda değer etkilerin kuzey batı Avrupa ülkelerinde görülmesi beklenirken, güney ve doğu Avrupa'daki bölgelerin daha az etkileneceği belirtilmektedir. Chen vd., bu dengesizliğin $\mathrm{BK}$ ile $\mathrm{AB}$ arasındaki müzakereleri etkileyebileceğini ifade etmektedir (Chen vd., 2018, s. 2526).

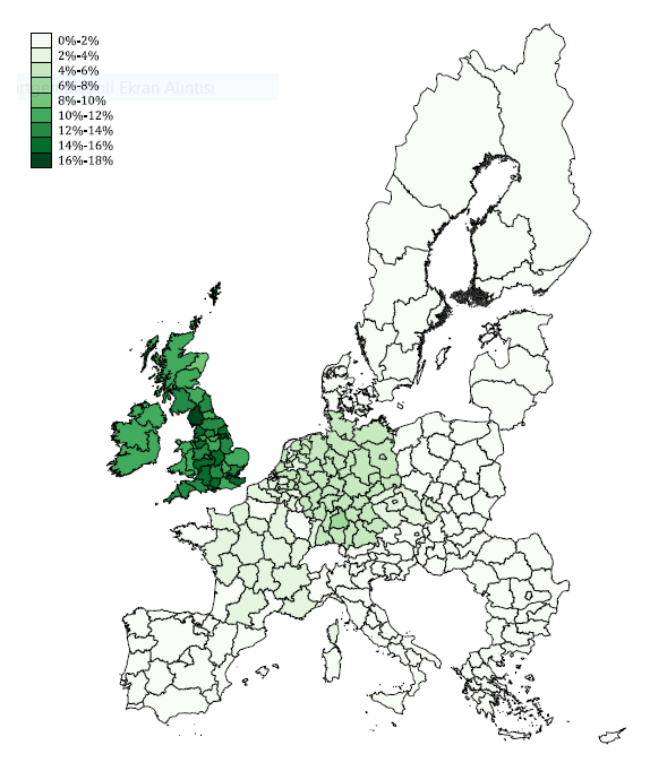

$\therefore \circ 8$

Sekil 3. Brexit'ten Etkilenen Yerel GSYIH (Chen, vd., 2018: 34).

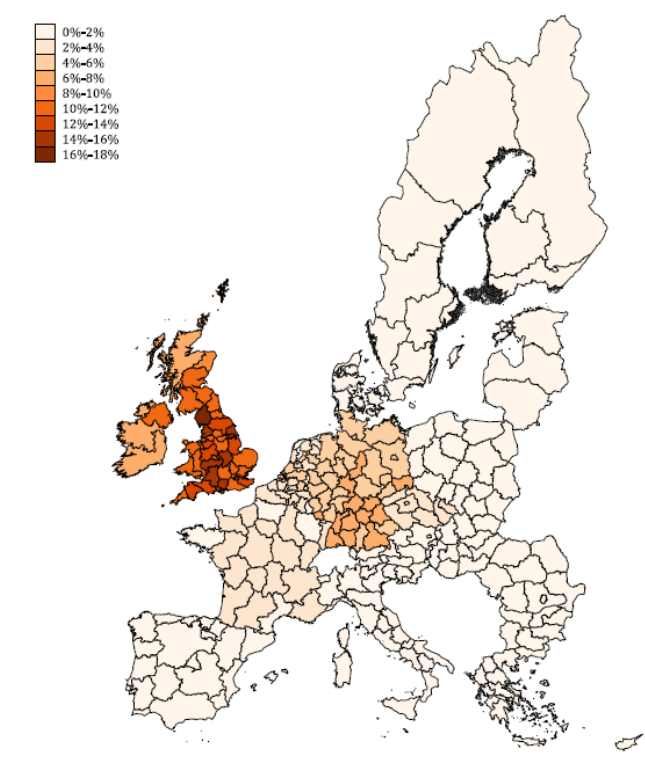

$\therefore \circ \circ$

Sekil 4. Brexit'ten Etkilenen Yerel İsgücü Geliri (Chen, vd., 2018: 35).

\section{Brexit'in Üçüncü Ülkeler Üzerindeki Etkilerini İnceleyen Çalışmalar}

Çin ekonomisinin Brexit'ten ciddi oranlarda etkilenmeyeceğini ifade eden Rothman (2016) çalışmasında, ABD ekonomisinde bir bozulma olmadığı müddetçe Çin ekonomisinde olumsuz etki 
yaşanmayacağını belirtmektedir. Asıl büyük endişe Brexit'in AB'de maddi bir gerilemeye yol açıp açmayacağıdır (Rothman, 2016, s. 2).

Garcia-Herrero ve Xu (2016) çalışmalarında, Brexit sonrası Çin ile BK arasında serbest ticaret anlaşmasının avantajlarını incelemişlerdir. Ancak böyle bir anlaşmaya varılmasının çok zor olacağını öne sürmüşlerdir (Garcia-Herrero ve Xu, 2016, s. 2).

Razzaque (2017) çalışmasında, Brexit sonrası Sahra-altı Afrika (SSA) için uygun kalkınma dostu ticaret rejimi uygulamasını ele almıştır. Brexit ile Ekonomik Ortaklık Anlaşmaları (EPA), on yıl aradan sonra tekrar gün yüzüne çıkmıştır. Razzaque'a göre BK'nin SSA için yeni ticaret politikası uygulaması zorunludur. BK ve AB, SSA için önemli ticaret ortaklarıdır. Brexit çalkantısı sürecinde SSA-AB (BK dahil) ticaretinde yavaşlama gerçekleşmiş, aynı dönemde Afrika ülkelerinde Çin ticareti artış göstermiştir. Ticaretteki bu gelişmeler 1şı̆̆ında Razzaque (2017, s. 58-61), BK'nin SSA ülkelerinin pazar erişimlerini güvence altına almak için yeni ticaret politikası uygulaması zorunda olduğunu belirtmiştir.

George'un (2017) yaptığı çalışmada da Razzaque'ın (2017) çalışmasına paralel olarak BK ve Afrika arasında gerçekleşmesi gereken Ekonomik Ortaklık Anlaşmalarını (EPA) ele alınmışırı. Brexit'in uzun vadede $\mathrm{BK}$ ve Afrika arasındaki ticari ilişkileri önemli ölçüde artıracağı fakat kısa ve orta vadede, firsatlar sunduğu kadar birçok problemi de beraberinde getireceği belirtilmiştir. BK, dinamik, açık iş modelleriyle Afrika çapında saygınlık kazanmıştır. Ticaret anlaşmalarında BK için en büyük dört Anglophone ülkesi (Nijerya, Güney Afrika, Kenya ve Gana) ve en büyük iki Francophone ülkesi (Côte d’Ivoire ve Senegal) önem taşımaktadır. Ancak Brexit müzakerelerinin en az iki yıl sürecek bir süreç olması, yeni ticaret anlaşmalarının önünde engel oluşturacaktır (George, 2017, s. 65).

Brexit’in Bangladeş ekonomisi üzerindeki etkilerini inceleyen bir çalışmaya göre iki ülke arasında ticari faydalardan yararlanmak için ikili anlaşmaların şart olduğu belirtilmiştir (Noor vd., 2016; T.C. Dişişleri Bakanllğı, 2018b).

Wood ve Jang (2017) çalışmalarında Brexit’in Asya ülkelerinin ekonomileri üzerindeki etkisini incelemişlerdir. Son zamanlarda çoğu Asya ülkesinin BK'ye olan ihracatı azalmış olsa da, BK'nin AB'den ayrılmasının Asya ülkelerini çok fazla etkilemeyeceğini ifade etmişlerdir. Yatırımlar açısından bir endişe söz konusu olabileceğini ifade etmişlerdir. Bununla birlikte Brexit'in Asya ülkelerine birtakım firsatlar sunabileceği sonucuna da varılmıştır. Singapur, Myanmar ve Malezya gibi ülkelerin BK ile olan ilişkilerinin zayıflaması dolayısıyla, bu ülkelerle serbest ticaret anlaşmaları müzakereleri başlatılabileceğini belirtmişlerdir.

PHD Chamber of Commerce and Industry (2016), Brexit'in Hindistan ekonomisinde büyük bir etki yaratmayacağını, Hindistan'ın herhangi bir sektöründe önemli bir etkisi olmadığını ileri sürmüştür.

\section{Brexit Sonras1 Senaryolar}

BK'nin Brexit anlaşması konusundaki tavr1 henüz netlik kazanmadığ1 için, $A B$ ile yürütülen müzakerelerin nasıl bir çıkış planına evrileceği belli değildir. BK'de Temmuz 2019'da Muhafazakar Parti liderliğine seçilecek olan liderin vizyonunun, süreci önemli ölçüde etkileyeceği düşünülebilir. Ancak diğer yandan May başbakanlığında, BK parlamentosunun Brexit anlaşmasını 3 kez red ettiği, sürecin anlaşmasız bir ayrılma seçeneği ile devam edebileceği de göz ardı edilmemelidir.

BK'nin $\mathrm{AB}$ ile ilişkilerinin 5 farklı şekilde devam edebileceği tartışılmaktadır: Avrupa Ekonomik Alanı'na (AEA) katılım (Norveç modeli), AB ile Gümrük Birliği (Türkiye modeli), AB ile serbest ticaret anlaşması, gelişmiş ikili anlaşmalar (İsviçre modeli) ve Dünya Ticaret Örgütü kuralları (üçüncü ülke modeli). Bu 5 modelin gerçekleşme ihtimali araştırmalarda tartışısa da, BK'nin kırmızı çizgisi olarak nitelendirilen hususlara göre bir seçeneğin müzakerelerde ön plana çıkacağı beklenebilir. BK; AB Adalet Divanı'nın yargı yetkisinin, $\mathrm{AB}$ düzenlemelerine uyumun ve $\mathrm{AB}$ bütçesine zorunlu katkının sona ermesini; AB'den gelen göçün kontrolü altında olmasını ve bağımsız bir ticaret politikası izlemeyi istemektedir (İktisadi Kalkınma Vakfi, 2018, s. 63-64).

Brexit’in AB üzerindeki sonuçları iki farklı bakış açısıyla değerlendirilmektedir. İlk bakış açısına göre Brexit, Avrupa dezentegrasyonu sürecidir. Avrupa gelecekte dezentegrasyon ve yanı sıra farklılaşmadan kaçamayacaktır. Hatta bazı araştırmacilar Brexit referandumunun "uluslararası dezentegrasyon" ve "demokratik kapitalizmde daha büyük bir krizin belirtisi” olarak nitelendirmiştir. Diğer bakış açısı AB'nin bir dezentegrasyon süreci içine girdiğini kabul etmekle birlikte, daha olumlu bir yaklaşıma sahiptir. Brexit; BK'nin AB ile "zorluk çıaran” ilişkisini sona erdireceğinden, Avrupa entegrasyonunu derinleştirmek için 
bir firsat olarak değerlendirilmektedir. Bu bakış açısına sahip çalışmalar, AB’nin, en gönülsüz üyelerinden birinden kurtulması sebebiyle artık entegrasyonu hızlandırabileceğini ileri sürmektedirler (Leruth, vd., 2019, s. 8-9).

Brexit sonrası AB'nin geleceği konusunda üç temel senaryo bulunmaktadır: Alman egemenliği, AB'nin dağılması veya Fransız-Alman işbirliği ile tazelenmiş bir AB. AB'nin hangi senaryoya göre değişeceği, Almanya'nın göreli duruşunun ne kadar güçlü olacağına ve Fransa'nın ekonomisini yedine yapılandırabilme becerisine bağlı olacaktır (Krotz ve Schild, 2018).

\section{Sonuç ve Öneriler}

$\mathrm{BK}$, henüz $\mathrm{AB}$ ile uzlaşılan Brexit anlaşmasını parlamentosunda onaylayamamıştır. BK'nin hangi şartlarda AB'den ayrılacağı henüz kesinlik kazanmamıştır. Üç kez red edilen anlaşma, Başbakan May'i istifaya götüren bir süreç ile devam etmektedir. Temmuz 2019'da seçilmesi beklenen yeni Muhafazakar Parti liderinin vizyonu şüphesiz süreci etkileyecektir. Ancak, BK'nin anlaşmasız ayrillğından yeni bir referandumun yapılmasına kadar pek çok seçenek, BK'nin iç siyasi gelişmelerine bağlı olarak gerçekleşebilir.

Brexit’in BK ekonomisi üzerinde yaratacağı etkileri konu alan ilk çalışmaların çok karamsar bir tablo ortaya koyduğu görülmektedir. Ancak sürecin üçüncü yllı itibariyle gerçekleşen sonuçların, beklenen sonuçlar kadar keskin olumsuz bir çizgide olmadığı söylenebilir. BK Merkez Bankası, telafi edici önlemler aldığı için, BK’nin ekonomik bunalıma sürükleneceği tahminleri doğru çıkmamıştır. Ekonomik etkiler konusunda gerçekleştirilen akademik çalışmaların, Brexit sürecindeki bölünmüşlüğün izlerini taşıyor olması dikkat çekicidir. Brexit’in ekonomik etkileri esasen müzakerelerin sonuçlarına bağlıdır.

BK, büyük bölgelerarası gelişmişlik farkl1lıklarının bulunduğu bir ülkedir. Brexit sonrası süreçte, özellikle uzun dönemde, ülkedeki bu dengesiz ekonomik gelişmişlik farklılı̆̆ın artacağı beklenmektedir. Gerçekleştirilen uygulamalı çalışmalar, ekonomik olarak BK'deki bölgelerin, diğer ülkelerdeki bölgelerden çok daha fazla etkileneceğini göstermektedir. İrlanda Cumhuriyeti'ndeki bölgelerde etki düzeyi; Londra ve kuzey İskoçya gibi en düşük etkiye maruz kalması beklen İngiliz bölgelerindekine benzer düzeylerdedir. Ekonomik coğrafya açısından en kayda değer etkilerin kuzey batı Avrupa ülkelerinde görülmesi beklenirken, güney ve doğu Avrupa'daki bölgelerin daha az etkileneceği belirtilmektedir.

Brexit'in AB'nin geleceği üzerindeki nasıl bir etkiye sahip olacağı iki farklı bakış açısıyla değerlendirilmektedir. İlk bakış açısına göre Brexit, Avrupa dezentegrasyonu sürecidir. Avrupa Brexit sonrası süreçte, benzer taleplerle karşılaşmaya devam edecektir. Diğer bakış açısı AB'nin bu dezentegrasyon sürecini olumlu bir yaklaşımla firsat olarak değerlendirmektedir. Brexit ile sürekli zorluk çıkaran bir İngiltere'den kurutulan AB, Avrupa entegrasyonunu derinleştirme ve hızlandırma firsatına sahip olacaktır. Ancak küresel ekonomideki genel yavaşlama nedeniyle bu iyimser yaklaşımın gerçekleşme ihtimalinin pek yüksek olmadığı değerlendirilmektedir.

Türkiye, Brexit’ten doğrudan etkilenen ülkelerden biridir. Kısa vadede, BK ile ticaretinde olumsuzluklar yaşaması kaçınılmazdır. BK'nin Gümrük Birliğ̊’nden de ayrılması durumunda, Türkiye ve BK'nin aralarında serbest ticaret anlaşması imzalaması gerekecektir.

Leruth vd., Brexit'in ,farklılaşmış dezentegrasyon örneği ve esnek entegrasyonun yeni bir şekli olarak araştırılmasını önermektedir (Leruth vd., 2019, s. 3). Farklılaşmış entegrasyon kuramsal çerçevesi içinde, tam üyelik statüsüne hala geçememiş olan Türkiye'nin önündeki seçeneklerin araştırılması önerilebilir.

Brexit sürecinde $\mathrm{BK}$ 'nin $\mathrm{AB}, \mathrm{AB}$ üyesi ülkeler ve Birlik dışında kalan ülkelerle ticari ilişkilerini çeşitli senaryolarla analiz eden ve geleceğe ilişkin ekonomik değerlendirmelerde bulunan uygulamalı çalışmalar bulunmaktadır. Türkiye'nin BK ile ekonomik ilişkilerinin çeşitli senaryolar açısından nasıl bir gelişim göstermesinin beklendiği konusunda uygulamalı araştırma gerçekleştirilmediği gözlenmiştir. Türkiye'nin önemli diş ticaret ortaklarından BK ile ticari ilişkilerinin, çeşitli senaryolara göre nasıl şekillenebileceğinin uygulamalı araştırmalarla değerlendirilmesi, Brexit sürecinde Türkiye'den BK'ye ihracat yapan endüstrilerin, süreci en az zararla atlatmaları için, uygun politika ve araçların tasarlanmasına yardımcı olacaktır.

\section{Kaynakça}

AB, Brexit'te geçiş sürecini belirledi. (2018, 29 Ocak). e-Dünya. https://www.dunya.com/ekonomi/ab-brexitte-gecissurecini-belirledi-haberi-400752 
Alaca, A.İ.S. (2017). Bölgesel ve uluslararası güvenlik açısından İngiltere'nin Avrupa Birliği’nden ayrılması (Brexit). Ed. E. Esen, \& D. Şekeroğlu. Brexit-Elveda Avrupa: Ingiltere'nin AB'den Ayrlmasindan Sonra Avrupa Bütünleşmesi Ve Türkiye-AB İlişkilerinde Fursatlar Ve Tehditler (pp. 265-298), Ankara: Siyasal Kitabevi. http://akvam.akdeniz.edu.tr/kitap/18.pdf

Aras, İ., \& Gunar, A. (2017). Brexit'in Avrupa Birliği-Türkiye ilişkilerine etkileri. Ed. T. Arı \& Ç.A. Koyuncu. IX. Uludağ Uluslararası İlişkiler Kongresi: Dünya Politikasinda Kriz ve Değişim (pp. 304-320). Bursa: Dora Basım Yayın.

Armstrong, K. (2018). Regulatory alignment and divergence after Brexit. Journal of European Public Policy, 25(8), 1099117. Doi: $10.1080 / 13501763.2018 .1467956$

Arnorsson, A., \& Zoega, G. (2018). On the causes of Brexit. European Journal of Political Economy, 55, $301-323$. https://doi.org/10.1016/j.ejpoleco.2018.02.001

Aybar, S. (2016, 27 Temmuz). Brexit sonras1, Ingiltere, AB ve ötesi. Türk Asya Stratejik Arastırmalar Merkezi. http://www.tasam.org/tr-TR/Icerik/31892/brexit_sonrasi_ingiltere_ab_ve_otesi

Aydemir, A. (2016). Brexit nedir? GCMFOREX Menkul Kzymetler A.Ş. https://www.gcmforex.com/egitim/makalearsivi/brexit-nedir/

Aykın, S.M. (2017). Brexit’te kırılma noktası: AB bütçesi. Ed. E. Esen, \& D. Şekeroğlu. Brexit-Elveda Avrupa: Ingiltere'nin AB'den Ayrlmasından Sonra Avrupa Bütünleşmesi Ve Türkiye-AB Illiskilerinde Fursatlar Ve Tehditler (pp. 215-245), Ankara: Siyasal Kitabevi. http://akvam.akdeniz.edu.tr/kitap/18.pdf

Barnes, P. (2019, 4 Haziran). Brexit: What happens now? BBC News. https://www.bbc.com/news/uk-politics46393399

Barrett, A., Bergin, A., FitzGerald, J., Lambert, D., McCoy, D., Morgenroth, E., Siedschlag, I., \& Studnicka, Z. (2015). Scoping The Possible Economic Implications Of Brexit On Ireland. İlanda: ESRI Research Series, 48. https://www.esri.ie/pubs/RS48.pdf

Bașkan, B. (2011). Krizdeki merkez sağ - yeniden konumlanma bunalımı. Liberal Düsünce, 16(63), 153-168.

Başkan, B. (2016, 28 Haziran). Brexit: Birleşik Krallık nereye. Yeni Şafak. https://www.yenisafak.com/hayat/brexitbirlesik-krallik-nereye-2487725

Başkan, B. (2017). Uncovering Western efforts for cultural hegemony over Turkey's July 15 coup attempt. Liberal Düsünce, 22(87), 107-116.

Başkan, B. (2019, 27 Nisan). Antisemitizm ve İslam karşıtlı̆̆1 arasında fark yok. Intel 4 Strategy News. https://www.intell4.com/dr-burak-baskan-antisemitizm-ve-islam-karsitligi-arasinda-fark-yok-haber-182469

Bergin, A., Garcia-Rodriguez, A., Morgenroth, E. L. W., \& Smith, D. (2017). Modelling the medium- to long-term potential macroeconomic impact of Brexit on Ireland. The Economic and Social Review, 48(3), 305-316. https://www.esr.ie/article/view/771/164

Birch, A. (2016). Brexit breakdown. KSLR EU Law Blog. https://blogs.kcl.ac.uk/kslreuropeanlawblog/?p=1054\#_edn10

Bootle, R., Jessop, J. Lyons, G., \& Minford, P. (2018, 21 Şubat). Alternative Brexit economic analysis. Economists For Free Trade. https://www.economistsforfreetrade.com/wp-content/uploads/2018/03/Alternative-BrexitEconomic-Analysis-Final-2-Mar-18.pdf

Brexit Hollandalı balıkçıları endişelendiriyor. (2018, 14 Mayıs). Euronewss, http://tr.euronews.com/2018/05/14/brexithollandal-bal-kcl-lar-endiselendiriyor

Brexit: İngiltere artı en büyük 5. ekonomi değil. (2016, 7 Temmuz). BBC News. https://www.bbc.com/turkce/ekonomi/2016/07/160707_ingiltere_brexit_ekonomi

Brexit müzakereleri bugün başliyor. (2017, 17 Temmuz). Hürriyet Gaz̧etesi. http://www.hurriyet.com.tr/ekonomi/brexit-muzakereleri-bugun-basliyor-40522451

Brexit müzakerelerinde ikinci aşama. (2017, 8 Aralı). Merkez Gazetesi. http://www.merkezgazetesi.com.tr/haber/brexit-muzakerelerinde-ikinci-asama-166290.html

Bulmer, S., \& Quaglia, L. (2018). The politics and economics of Brexit. Journal of European Public Policy, 25(8), 10891098. Doi: $10.1080 / 13501763.2018 .1467957$

Cambridge University Press (2019). Eurosceptic. Cambridge Advanced Learner's Dictionary \& Thesaurus. https://dictionary.cambridge.org/tr/sözlük/ingilizce/eurosceptic

Carter, A., \& Swinney, P. (2019). Brexit and the future of the UK's unbalanced economic geography. The Political Quarterly, 90(2), 72-83. https://doi.org/10.1111/1467-923X.12649

Chang, W.W. (2018). Brexit and its economic consequences. The World Economy, 41(9), $2349-2373$. https://doi.org/10.1111/twec.12685

Chen, W., Los, B., McCann, P., vd. (2018). The continental divide? Economic exposure to Brexit in regions and countries on both sides of The Channel. Papers in Regional Science, 97(1), 25-54. https://doi.org/10.1111/pirs.12334

Colantone, I., \& Stanig, P. (2018). Global competition and Brexit. American Political Science Review, 112(2), 201-218. Doi:10.1017/S0003055417000685

Cookman, L. (2016, 25 Mays). What if Turks talked about Britons the way vote leave talks about Turkey? The Guardian. https://www.theguardian.com/commentisfree/2016/may/25/vote-leave-turkey-british-migrantsturks-ankara-eu\#img-2 
Çenberci, E., \& Gövdere, B. (2017). Göç krizinin, Brexit kararına ve Avrupa Birliği’nin geleceğine muhtemel etkileri. Süleyman Demirel Üniversitesi İktisadi ve İdari Bilimler Fakültesi Dergisi, 22(Göç Özel Sayıs1), 1427-1442.

Çetin, Ş., \& Hatip, Y. (2018). Brexit sonrası ilk AB bütçesi birliği böldü. Anadolu Ajansı. https://www.aa.com.tr/tr/dunya/brexit-sonrasi-ilk-ab-butcesi-birligi-boldu/1139786

Dennison, J., \& Geddes, A. (2018). Brexit and the perils of 'Europeanised' immigration. Journal of European Public Policy. Doi: 10.1080/13501763.2018.1467953

Deutscher Industrie-und Handelskammertag (2017). The Impact Of Brexit On German Businesses Results Of The IHK Business Survey Going International 2018. Berlin: DIHK.

Elbir, H.Ç. (2018). Brexit süreci yürüyor ama İngiltere Avrupa'dan çıkmak istemiyor. Avrasya Incelemeleri Merkęi, Yorum no: 2018/19. https://avim.org.tr/tr/Yorum/BREXIT-SURECI-YURUYOR-AMA-INGILTEREAVRUPA-DAN-CIKMAK-KONUSUNDA-TEREDDUTLU

Eluere, M., \& Martin, L. (2016). France - How will Brexit impact the French economy? Prospects, 16(178). http://etudes-economiques.mobi/medias/Persp16_178_France_20160704_EN.pdf

Eralp, N.A. (2016). Brexit'in AB üzerindeki etkileri: ilk tahminler. Türkiye Ekonomi Politikalar Araștorma Vakefi, Değerlendirme Notu. Temmuz 2016. http://www.tepav.org.tr/upload/files/14677963245.BREXIT__IN_AB_UZERINDEKI_ETKILERI_ILK_TAHMINLER.pdf

Gamble, A. (2018). Taking back control: the political implications of Brexit. Journal of European Public Policy, 25(8), 1215-1232. Doi: 10.1080/13501763.2018.1467952

Garcia-Herrero, A., \& Xu, J. (2016). What consequences would a post-Brexit China-UK trade deal have for the EU? Policy Contribution, 18, Brussels: Bruegel.

George, E. (2017). A private sector perspective on priorities for UK-Africa trade relations post Brexit. The Future Of Africa-Uk Trade And Development Cooperation Relations In The Transitional And Post Brexit Period (pp. 65-68). All Party Parliamentary Group for Africa. http:/ / www.royalafricansociety.org/sites/default/files/files/APPG\%20report $\% 202017$ $\% 20$ Future $\% 20$ of $\% 20$ Africa $\% 20$ UK $\% 20$ Relations $\% 20$ Post $\% 20$ Brexit $\% 20 v 2$.pdf

Gürlesel, C.F. (2016). Brexit ve küresel etkileri. Moment Expo, 97. http://www.moment-expo.com/brexit-ve-kureseletkileri

Hantzsche, A., Kara, A., \& Young, G. (2019). The economic effects of the UK government's proposed Brexit deal. The World Economy, 42, 5-20. Doi: 10.1111/twec.12770

House of Lords (2016). The EU referendum and EU reform. European Union committee 9th report of session 2015-16, HL Paper 122. London.

Ignáth, É. K. (2017). The impact of Brexit on the Benelux states. Essays in Economics and Business Studies. doi: 10.18427/iri-2017-0059

İktisadi Kalkınma Vakfi (2018). Birleşik. Krallk Referandumu ve Sonrası: AB Entegrasyon Sürecinin Geleceği ve Türkiye. (2. Baskı), İstanbul: İktisadi Kalkınma Vakfi Yayınları, $\quad$ Yayın no: 298. https://www.ikv.org.tr/images/ files/brexit2018\%20(7)(1).pdf

Ingiltere AB'den ayrıldı! peki şimdi ne olacak?. (2016, 24 Haziran). Takvim Gazetesi. https://www.takvim.com.tr/galeri/dunya/ingiltere-abden-ayrildi-peki-simdi-ne-olacak/19

İngiltere ulusal kanunlarına dönüyor. (2017, Mart 31). Mepa News. https://www.mepanews.com/ingiltere-ulusalkanunlarina-donuyor-4984h.htm

Ingiltere ve $A B$, Brexit müzakerelerinde ikinci aşamaya geçiyor. (2017, 15 Aralık). BBC News. https://www.bbc.com/turkce/haberler-dunya-42366180

İngiltere: işsizlik son çeyrekte düştü ancak Brexit istihdam için endişe kaynağı. (2016, 16 Kasım). Euronews. http://tr.euronews.com/2016/11/16/ingiltere-issizlik-son-ceyrekte-dustu-ancak-brexit-istihdam-icin-endisekaynagi

İstanbul International Finance Center (2018). Londra uluslararası finans merkęi. http://iifc.com.tr/londra-uluslararasifinans-merkezi/

Karacan, P. (2017). Brexit: Avrupa Birliği Hukuku ve Birleşik Krallık açısından 'buzdağının görünen yüzü’. Dokur Eylül Üniversitesi Sosyal Bilimler Enstitüsü Dergisi, 19(3). 403-416.

Kılcı, E.N. (2018). Brexit; Birleşik Krallık ve Euro-Bölgesi açısından sonuçlarının değerlendirilmesi. Sakarya İktisat Dergisi, 7(1), 1-26.

Kolev, G., Matthes, J., \& Busch, B. (2016). Brexit impacts on Germany? IW-Kur₹berichte. https://www.iwkoeln.de/en/studies/iw-kurzberichte/beitrag/galina-kolev-juergen-matthes-berthold-buschbrexit-impacts-on-germany-305825.html

Komaromi, P., \& Singh, K. (2016). Post-referendum racism and xenophobia: the role of social media activism in challenging the normalisation of xeno-racist narratives. PostRef Racism. http://s3-eu-west2.amazonaws.com/wpmedia.outlandish.com/irr/2017/04/26154821/PRRX-Report-Final.pdf

Köker, İ. (2017, 19 Haziran). Brexit müzakereleri AB'nin bazırladiğı çerçevede ilerleyecek. https://www.bbc.com/turkce/haberler-turkiye-40336341

Krotz, U., ve Schild, J. (2018). Back to the future? Franco-German bilateralism in Europe's post-Brexit Union. Journal of European Public Policy, 25(8), 1174-1193. Doi: 10.1080/13501763.2018.1467951

Küçükkeleş, M. (2013). AB'nin Ortadoğu politikası ve Arap Baharına bakışı. SETA Analiz, 63. http:// file.setav.org/Files/Pdf/20130118172742_seta_analiz_ab_arap_bahari.pdf 
Lammersen, J. (2017, 3 Ekim). A look at the potential impact of Brexit on the Dutch economy. Focus Economics. https://www.focus-economics.com/blog/potential-impact-brexit-dutch-economy

Leruth, B, Gänzle, S., \& Trondal, J. (2019). Exploring differentiated disintegration in a post-Brexit European Union. Journal of Common Market Studies, 1-18. Doi: 10.1111/jcms.12869

Miller, V. (2015, 3 Temmuz). The 1974-75 UK renegotiation of EEC membership and referendum. House of Commons Library Briefing Paper no. 7253.

Minford, P. (2019). The effects of Brexit on the UK economy. The World Economy, 42(1), 57-67. https://doi.org/10.1111/twec.12771

Noor, T., Islam, S., Alam Nirob, K. J., \& Hossain, M. (2016). Brexit and the impact on Bangladesh. Imperial Journal of Interdisciplinary Research, 2(12), 68-76.

Office for National Statistic (2016). Estimates of employment, unemployment, economic inactivity and other employment related statistics for the UK. UK Labour Market.

Office for National Statistic (2018). Who does the UK trade with? https://www.ons.gov.uk/businessindustryandtrade/internationaltrade/articles/whodoestheuktradewith/2017$02-21$

Petroff, A. (2017, 22 Kasim). Britain crashes out of world's top 5 economies. CNN Business. https://money.cnn.com/2017/11/22/news/economy/uk-france-biggest-economies-in-the-world/index.html

PHD Chamber of Commerce and Industry (2016). Brexit impact on Indian economy. Working Paper. 43. Hindistan. http://phdcci.in/live_backup/image/data/Research\%20Bureau2014/Economic\%20Developments/paper/BREXIT\%20Impact.pdf

Razzaque, M. A. (2017). Post-Brexit UK-africa trading relationship: can it be more development-friendly than EPAs? The Future Of Africa-Uk Trade And Development Cooperation Relations In The Transitional And Post Brexit Period (pp. 5861). All Party Parliamentary Group for Africa. http://www.royalafricansociety.org/sites/default/files/files/APPG $\% 20$ report $\% 202017$ $\% 20$ Future $\% 20$ of $\% 20$ Africa $\% 20$ UK $\% 20$ Relations $\% 20$ Post $\% 20$ Brexit $\% 20$ v2.pdf

Rothman, A. (2016, 8 Temmuz). Brexit impact on China. Advisor Perspectives. Matthews Asia. https://www.advisorperspectives.com/commentaries/2016/07/08/brexit-impact-on-china

Salvatore, D. (2017). Europe's growth crisis: when and how will it end? The World Economy, 40(5), 836-848. https://doi.org/10.1111/twec.12460

Schimmelfennig, F., Leuffen, D., \& Rittberger, B. (2015). The European Union as a system of differentiated integration: interdependence, politicization and differentiation. Journal of European Public Policy, 22(6), 764-82.

Schimmelfennig, F. (2018). Brexit: differentiated disintegration in the European Union. Journal of European Public Policy, 25(8), 1154-1173. Doi: 10.1080/13501763.2018.1467954

Sefer, Ö. (2014). Birleşik Krallık-Avrupa Birliği ilişkileri üzerine bir inceleme. Marmara Sosyal Araştırmalar Dergisi. 6, 4761. http://dspace.marmara.edu.tr/handle/11424/4047

Stanciu, S. (2016). Brexit impact on Romania's economy. Proceedings of the $28^{\text {th }}$ IBIMA Conference Vision 2020: Innovation Management, Development Sustainability, and Competitive Economic Growth. 2307-2315.

T.C. Dişişleri Bakanlığ1 (2018a). Türkiye-Birleşike Krallk Ilişkileri. http://www.mfa.gov.tr/turkiye-ingiltere-siyasiiliskileri.tr.mfa

T.C. Dişişleri Bakanlığ1 (2018b). Bangladeş'in Ekonomisi. http://www.mfa.gov.tr/banglades-ekonomisi.tr.mfa

T.C. Londra Büyükelçiliği Ticaret Müşavirliği (2010). Ingiltere'nin Genel Ekonomik. Durumu ve Türkiye ile Ekonomik-Ticari İiskileri.

Taggart, P. (1998). A touchstone of dissent: Euroscepticism in contemporary Western European party systems. European Journal of Political Research, 33, 363-388.

Taggart, P., \& Szczerbiak, A. (2002). The party politics of Euroscepticism in EU member and candidate states. Opposing Europe Research Network Working Paper, No.6, 1-45.

The Chamber of Commerce and Industry of Romania (2017). The Effects of Brexit on The Romanian Economy. Challenges and Opportunities at The European Level. Romania. https://ccir.ro/wp-content/uploads/2014/11/Fact-sheet-onBrexit-1.pdf

The Conservative leadership which Boris would Britain get? (2019, 20 Haziran). The Economist. https://www.economist.com/leaders/2019/06/20/which-boris-would-britain-get

Torreblanca, J.I., \& Leonard, M. (2013). The Continent-Wide Rise of Euroscepticism. European Council on Foreign Relations, Policy Memo 79, United Kingdom.

Türkiye Otelciler Birliği (2017). 2017 WTM turiż fuar TÜROB fuar sonuc raporu. http://www.turob.com/Resources/doc/wtm2017.pdf

Tüysüzoğlu, G. (2013). İngiltere AB'den kopuyor mu?. Uluslararası Politika Akademisi. http://politikaakademisi.org/2013/01/31/ingiltere-abden-kopuyor-mu/

UK unemployment rate falls to fresh 11-year low. (2016, 20 Temmuz). BBC News, https://www.bbc.com/news/business-36844302

Ultan, M.O., \& Ornek, S. (2015). Euroscepticism in the European Union. International Journal of Social Sciences, 4(2), 4957. Doi: $10.20472 /$ SS.2015.4.2.006

Uzunluoz, E. (2018). Brexit'in Türkiye ve Avrupa'ya etkisi. Diplomatik Strateji Araşttrma Merkez̧. https://www.diplomatikstrateji.com/brexitin-turkiye-ve-avrupaya-etkisi/ 
Velthuijsen, J.W., \& Bernard, L. (2016). Brexit Monitor the Impact of Brexit on (Global) Trade. Pwc.nl. https://www.pwc.nl/nl/brexit/documents/pwc-brexit-monitor-trade.pdf

Velthuijsen, J.W., Kramer, G., \& Yildirım, B. (2018). European Economic Outlook 2018-2022. Pwc.nl. https://www.pwc.nl/nl/themas/europe-monitor/documents/pwc-european-economic-outlook-2018.pdf

Virdee, S., \& McGeever, B. (2018). Racism, crisis, Brexit. Ethnic and Racial Studies, 41(10), 1802-1819. Doi: 10.1080/01419870.2017.1361544

Wood, J., \& Jang, H. (2017). Brexit: the economic and political implications for Asia. Social Sciences, 6(41). https://doi.org/10.3390/socsci6020041

\section{EXTENDED ABSTRACT}

UK was projected to leave EU by March 2019. But the process has fallen behind schedule, UK hasn't left EU membership yet. UK Parliament has rejected the Brexit deal for three times and UK requested postponement from EU, twice. UK Prime Minister May, has resigned from the leadership of the Conservative Party, and new party leader is expected to be chosen in July 2019. Uncertainty still prevails, as Conservative Party leader candidates' attitudes on how Brexit process should be progressed differ from each other. Whoever becomes the new leader of the Conservative Party, will determine the leaving terms (Barnes, 2019).

Early studies concerning effects of Brexit on UK economy depicted a very pessimistic view. But in the end of third year, the realized results have not sharply revealed a negative prospect, as bad as expected. Remarkably, academic studies on economic effects, also bear the traces of dividedness of Brexit period. According to many economists, UK will inevitably lose, but the degree of loss may vary depending on the terms of leaving process. On the other hand, leave supporter economists claim that; the economic analysis suggesting UK to get in to a turmoil and absolutely lose, were not based on a convenient method; and EU is not a story of success, therefore UK will certainly benefit from this separation in case of short-term negative incidents (Minford, 2019; Bootle et al., 2018).

Migrants coming from new member states to UK, and future migrations expected from non-member states like Turkey, were used in "leave" campaigns; and this is interpreted as xenophobia is on the rise in UK. For migrants in UK, leave decision of Brexit referendum, means an exit from the EU legal framework on human rights and fundamental freedoms and non-discrimination. In this context, foreigners living in UK are seemed to be concerned about, UK's turning into a closed country after leaving EU, and losing their job and education opportunities. Besides, in parallel with the political discourse used in Brexit campaigns, racist attacks have risen (Başkan, 2019). 6.000 hate crimes were reported in the first four-week period after referendum result was declared (Komaromi, 2016). But the Anglo-Saxon secular tradition in UK, is established over non-interference of state and religion to each other; and it will not let legal regulations to be made, strict enough to change migrants' lives, in period following Brexit (Başkan, 2019).

UK's leaving EU will directly affect Turkey. Turkey's losing an important supporter for her EU membership, is frequently stated (Gürlesel, 2016, p. 100). UK officially supports Turkey's membership to EU; but in practice, it is contentious at which extend UK supports Turkey's membership. During the Brexit referendum campaigns, questions concerning Turkey's EU membership had been answered by Cameron, stating that Turkey will not become a member until year 3.000 (İktisadi Kalkinma Vakfi, 2018: 72). On the other hand, an important phase for Turkey, the decision to start Turkey's accession negotiations, had been made under UK's presidency of the EU (T.C. Londra Büyükelçiliği Ticaret Müşavirliği, 2010, p. 30).

UK is known to be the country possessing highest number of foreign investments in Turkey, and there are more than 2900 companies with British capital in Turkey. Approximate value of these investments are 9 billion 538 million USD. Since 2001, trade balance between Turkey and UK, has progressed in favour of Turkey, with a consistent trade surplus, and increased by $78,8 \%$. UK had ranked in 11th place in Turkey's import partners and 2nd place in export partners; after Brexit, in the first quarter of 2017, compared to same period in the previous year, foreign trade between two countries has narrowed by $14 \%$ and UK has declined to 4th place among major export countries (T.C. Dişişleri Bakanlığ1, 2018a).

During the "leave" campaigns, Turkey's EU membership was qualified as a "threat"; and in case of not leaving the EU, UK will face a Muslim migration flow and a radical Islamic threat, were frequently expressed (Uzunluoz, 2018; Aras, \& Gunar, 2017: 307). News in many broadcasting institutions- including BBC- describing the coup attempt in July 15th 2016 in Turkey, as a hopeful attempt carried out by 
reformist Muslims; indicate that the political events in Turkey are not accurately interpreted (Başkan, 2017, p. 112-114).

On the other hand, EU membership is frequently used as a domestic political issue and parties adopt contrary attitudes in opposition and in power, in Turkey (Başkan, 2011: 166). Similarly, Turkey's EU membership has become a domestic political issue in UK in the Brexit period. Conservative Party leader candidate Boris Johnson, is currently against Turkey's EU membership, but was a supporter previously (“The Conservative Leadership Which Boris Would Britain Get?", 2019).

Leruth et al. suggest that Brexit should be studied as an example of differentiated disintegration and a new form of flexible integration (Leruth et al., 2019, p. 3). Within the theoretical framework of differentiated integration, options for Turkey should also be studied, as she still does not possess a full membership.

There are empirical studies focusing on future economic effects of Brexit, UK's relations with EU, EU member countries and the countries outside the Union, according to varying scenarios. Turkey's economic relations with UK and prospects for the future according to varying scenarios, is not studied with applied studies. Studies analysing Turkey's trade relations with one of her most important foreign trade partners, UK; will help to design and implement appropriate policy and tools for exporting industries of Turkey, to overcome the Brexit aftermath with lesser loss. 